\title{
FIRST RECORD OF THE SINO-HIMALAYAN SPECIES DEYEUXIA HIMALAICA IN YUNNAN PROVINCE, SW CHINA, AND THREE NEW COMBINATIONS IN CALAMAGROSTIS (POACEAE, AGROSTIDINAE)
}

\author{
Beata Paszko
}

\begin{abstract}
As a result of recent studies of worldwide Agrostidinae, Deyeuxia gaoligongensis Paszko, D. himalaica Liou ex W. L. Chen and D. sorengii Paszko \& W. L. Chen are here recombined as Calamagrostis gaoligongensis comb. nov., C. himalaica comb. nov. and $C$. sorengii comb. nov., respectively, and the first record of the Sino-Himalayan species $C$. himalaica from Yunnan Province, southwestern China, is reported. Calamagrostis himalaica occurs primarily in southeast Xizang, southwestern China, with a single locality recorded recently in Kachin State, Myanmar (Burma). A map with all known geographic records of $C$. himalaica and an image of the newly identified specimen are presented.
\end{abstract}

Key words: Asia, distribution, Gaoligong Shan, Hengduan Mts, nomenclature, taxonomy

Department of Vascular Plant Systematics and Phytogeography, W. Szafer Institute of Botany, Polish Academy of Sciences, Lubicz 46, 31-512 Kraków, Poland; e-mail: b.paszko@botany.pl

\section{INTRODUCTION}

Sequence data from nuclear ribosomal regions (ITS, ETS) have revealed that the Eurasian species Calamagrostis Adans. and Deyeuxia Beauv. are closely related (Saarela et al. 2010; J. M. Saarela, unpubl. data). Currently, a new taxonomic treatment of Calamagrostis (including Deyeuxia) is being prepared for Flora of PanHimalayas (Paszko, unpubl.). Three Chinese species originally described under the genus $D e$ yeuxia - D. gaoligongensis Paszko, D. himalaica Liou ex W. L. Chen and D. sorengii Paszko \& W. L. Chen (Chen 2001; Paszko \& Chen 2013; Paszko \& Pendry 2013) - are here recombined as Calamagrostis gaoligongensis comb. nov., C. himalaica comb. nov. and C. sorengii comb. nov., respectively.

In Yunnan Province, China, Calamagrostis is represented by 3 species and Deyeuxia by 16 (Sun $2003 a, b)$. Recent taxonomic studies by me and co-workers revealed a number of taxonomic novelties within the genera Calamagrostis and Deyeuxia in Yunnan Province. These include a new species from the Gaoligong Shan range in northwestern Yunnan, D. gaoligongensis (Paszko \& Pendry
2013), and the first records of Calamagrostis debilis Hook. f., C. filiformis Griseb. and C. yanyuanensis J. L. Yang in Yunnan Province (Paszko 2012; Paszko et al. 2013; Nobis et al. 2014). This work has helped clarify some of the taxonomic confusion surrounding old and new names. The taxonomic revision showed that Calamagrostis tripilifera Hook. f. is the valid name for Yunnan specimens previously identified as Deyeuxia flavens Keng (Paszko 2012). Paszko and Soreng (2013) clarified the tangled taxonomy of two species occurring in Yunnan, Calamagrostis abnormis (Hook. f.) Shukla and C. diffusa (Keng) Keng f. Taxonomic study of the Calamagrostis epigeios (L.) Roth complex showed that in Yunnan the species misidentified as C. epigeios s.str. corresponds to $C$. extremiorientalis (Tzvel.) Prob. (Paszko $\&$ Ma 2011). A recent revision of the collections at herbarium $E$ revealed the presence of one more species not reported from Yunnan Province before. This paper documents the occurrence of Calamagrostis himalaica in northwestern Yunnan (SW China), and extends its known distribution range considerably. 


\section{MATERIAL AND METHODS}

All revised localities of Calamagrostis himalaica mentioned in the text are shown on a map (Fig. 1) made with SimpleMappr (http://www.simplemappr.net). Geographic coordinates are given for each locality. If that information was not part of the original collection data, approximate coordinates are given in square brackets. The approximate coordinates for the collecting site in northern Myanmar, Tamā Bum Mt., were taken from Kingdon-Ward (1954: 304), and for Doshong La from Stearn (1976: 261). Doshong La is marked on an excellent map of southeastern Tibet showing the routes of Ludlow and his associates in eastern Himalaya (Ludlow 1940).

\section{TAXONOMIC TREATMENT}

Calamagrostis himalaica (Liou ex W. L. Chen emend. Paszko) Paszko, comb. nov. Figs 1 \& 2

Basionym: Deyeuxia himalaica Liou ex W. L. Chen, Acta Phytotax. Sin. 39: 447. 2001, emend. Paszko, Phytotaxa 156(5): 285. 2014.

Type: CHINA. Xizang. Mêdog Xian, South Doshong $\mathrm{La}$, in alpine meadow, 3900-4000 m a.s.l., [29.48333 $\left.{ }^{\circ} \mathrm{N}, 94.98333^{\circ} \mathrm{E}\right], 14$ Sept. 1974, leg. Qinghai Xizang Exped. 1033 (HOLOTYPE: PE).

Deyeuxia himalaica was invalidly described by Liang Liou (1933-2001) (in Lu \& Liou 1987; in Lu 1987). The name was validated by Chen (2001: 447). Paszko (2014) discussed the taxonomy of Deyeuxia himalaica and gave an emended description and diagnosis of this species.

Calamagrostis himalaica is closely related to C. scabrescens Griseb., a highly polymorphic complex in Southeast Asia (Lu et al. 2006; Paszko 2014). The former is similar to the latter, especially in spikelet morphology, but they differ in the texture of the upper leaf blade surface. Calamagrostis himalaica has deep furrows and ribs and a densely scabrous upper leaf blade surface, whereas $C$. scabrescens has a moderately ribbed and lightly to moderately scabrous upper leaf blade surface. The typical morphotype of $C$. himalaica has one-flowered spikelets; two-flowered spikelets are atypical (Paszko 2014). In specimens from the Gaoligong Shan range only one-flowered spikelets were noted

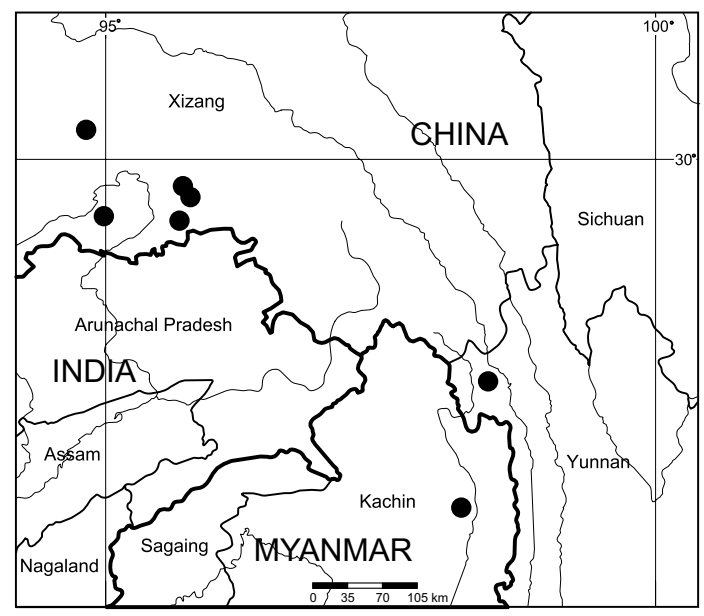

Fig. 1. Distribution map with all known geographic records of Calamagrostis himalaica (Liou ex W. L. Chen, emend. Paszko) Paszko in China (Xizang and Yunnan) and Myanmar (Kachin).

in the panicles. For more taxonomic details see Paszko (2014).

Distribution: Calamagrostis himalaica was previously known only from China, where it was recorded in Bomê County and Mêdong County in southeastern Xizang (Chen 2001; Lu et al. 2006). Recently, Paszko (2014) noted its first record from the north part of the mountainous region known as the Triangle, in Kachin State (northern Myanmar) north of Myitkyina. It was collected there by Kingdon-Ward on the slopes of the highest peak in this area, called Tamā Bum (3610 m a.s.l.), at $3200 \mathrm{~m}$ a.s.l. (Kingdon-Ward 1954).

In July 2015, during revision of Himalayan collections of the genus at E, $C$. himalaica was noted for the first time among unidentified collections of Calamagrostis from the east side of the Gaoligong Shan range in western Yunnan, southwestern China (Fig. 2). The Gaoligong Shan range, at the southern end of the Hengduan Mountains, forms the border between Myanmar and China. Calamagrostis himalaica was collected there in August 2006 by the Gaoligong Shan Biodiversity Survey Group in the vicinity of Bingzhongluo in the district of Gongshan.

Calamagrostis himalaica is restricted to the Sino-Himalayan forest subkingdom ( $\mathrm{Wu} \& \mathrm{Wu}$ 1998; Paszko 2014; Tang 2015). It has been 


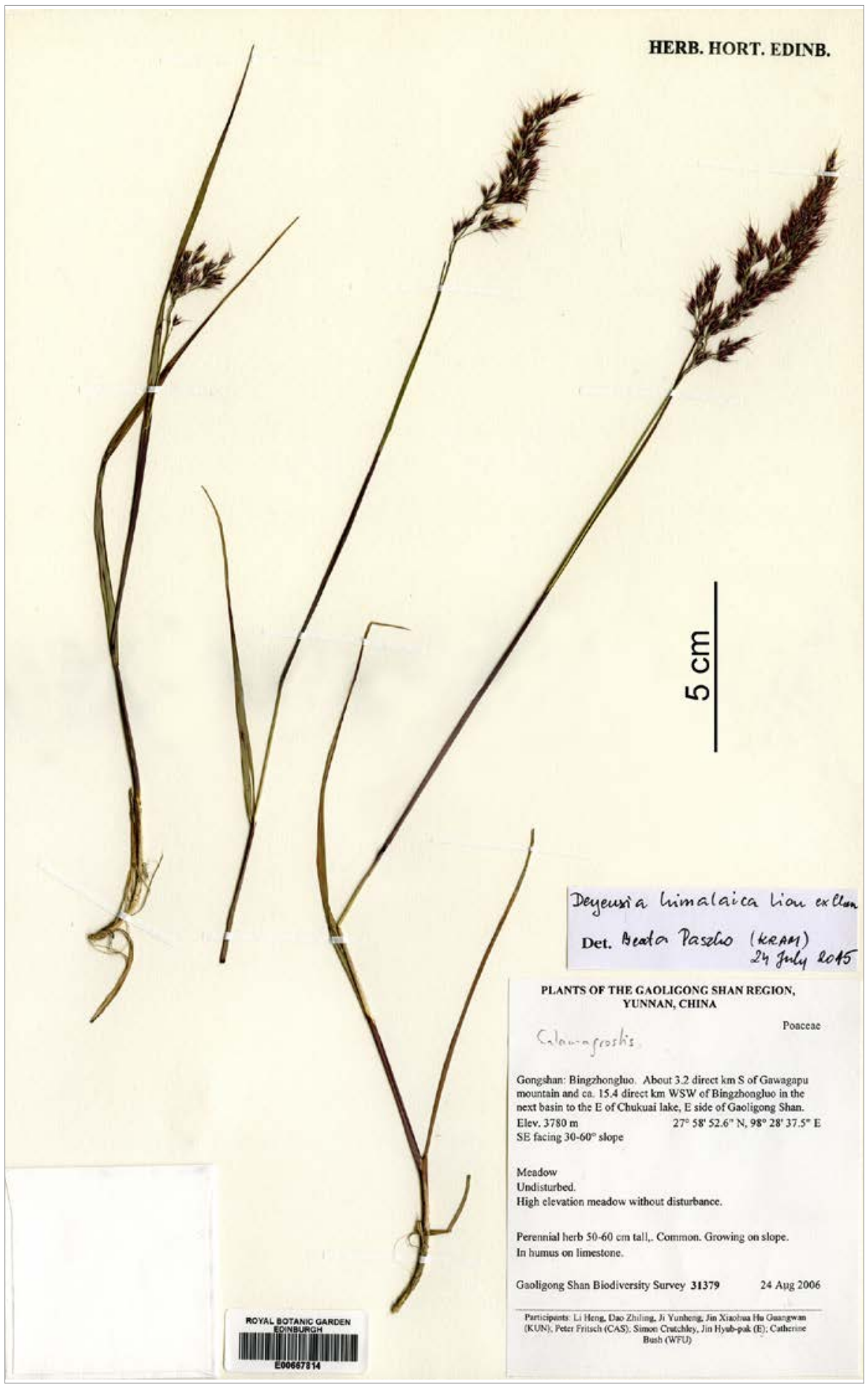

Fig. 2. Specimens of Calamagrostis himalaica (Liou ex W. L. Chen, emend. Paszko) Paszko from a newly discovered locality in Yunnan (E00667814). 
recorded in the South Hengduan Mountain subregion of the Hengduan Mountain region, and in two subregions of the East Himalayan region: the Southeast Xizang subregion, and Taron-Taru (Irrawaddy) - North Myanmar subregion.

HaBitat. Calamagrostis himalaica grows in the Gaoligong Shan range in undisturbed meadows at $3780 \mathrm{~m}$ a.s.1. in the subalpine zone. In Bomi County and Mêdog County (SE Xizang) it occurs in the subalpine zone at 3400 and $4000 \mathrm{~m}$ a.s.l., and on Myanmar's Irrawaddy Plateau ca 3200 m a.s.l. (Paszko 2014).

Specimens examined: CHINA. Yunnan [first record]. Gongshan Co., Bingzhongluo. About 3.2 direct $\mathrm{km} \mathrm{S}$ of Gawagapu Mt. and $c a 15.4$ direct $\mathrm{km}$ WSW of Bingzhongluo in the next basin to the $\mathrm{E}$ of Chukuai lake, E side of Gaoligong Shan, alt. 3780 m, $27.98128^{\circ} \mathrm{N}, 98.47708^{\circ} \mathrm{E}$, common in high elevation meadows without disturbance, growing on slope, in humus on limestone, 24 Aug. 2006, leg. Gaoligong Shan Biodiversity Survey 31379 (E00667814). XIZANG. Bomi Co.: N slope of Mt. Jizhula, alt. $3700 \mathrm{~m}$, [29.65683 $\left.{ }^{\circ} \mathrm{N}, 95.77083^{\circ} \mathrm{E}\right], 2$ Sept. 1980 , leg. Plateau Pl. Exped., Dept. of Ecology, Institute of Botany, CAS 14820 (PE01727278); N slope of Mt. Jizhula, alt. 3500$3800 \mathrm{~m},\left[29.65683^{\circ} \mathrm{N}, 95.77083^{\circ} \mathrm{E}\right], 2$ Sept. 1980 , leg. Plateau Pl. Exped., Dept. of Ecology, Institute of Botany, CAS 14824 (PE01727277, PE00468320); Mt. Galongla, alt. $3500-3800 \mathrm{~m},\left[29.75633^{\circ} \mathrm{N}, 95.70217^{\circ} \mathrm{E}\right], 6 \mathrm{Sept}$. 1980, leg. Plateau Pl. Exped., Dept. of Ecology, Institute of Botany, CAS 14932 (PE01727275, PE01727279); Mt. Galongla, alt. $3500-3800 \mathrm{~m},\left[29.75633^{\circ} \mathrm{N}, 95.70217^{\circ} \mathrm{E}\right]$, 6 Sept. 1980, leg. Plateau Pl. Exped., Dept. of Ecology, Institute of Botany, CAS 14940 (PE01727273); N slope of Mt. Galongla, alt. $3500-3800 \mathrm{~m},\left[29.75633^{\circ} \mathrm{N}\right.$, 95.70217 ${ }^{\circ} \mathrm{E}$ ], 16 Aug. 1982, leg. Cheng \& Li 146 (PE01727286, PE01727287); Bana Pass behind Yigong Farm, alt. $3400-4000 \mathrm{~m},\left[30.26883^{\circ} \mathrm{N}, 94.82233^{\circ} \mathrm{E}\right], 18$ Aug. 1983, leg. Li, Ni \& Cheng 6674 (PE01727276, PE01727282, PE01727283). Mêdog Co.: Doshong La, Kongbo, alt. $3810 \mathrm{~m},\left[29.48333^{\circ} \mathrm{N}, 94.98333^{\circ} \mathrm{E}\right]$, grass on the banks of the stream, 15 Aug. 1947, leg. F. Ludlow, G. Sherriff \& H.H. Elliot 14353 (BM001050218; CAL, herb. no. 537180; E; L0834291); Gedang, E slope of Mt. Bengbengla, alt. $3500-3800 \mathrm{~m}$, [29.44267 ${ }^{\circ} \mathrm{N}, 95.671^{\circ} \mathrm{E}$ ], 7 Oct. 1982, leg. Li \& Cheng 1126 (PE01727274, PE01727280, PE01727281); S slope of Mt. Galongla, alt. $3700 \mathrm{~m},\left[29.75633^{\circ} \mathrm{N}, 95.70217^{\circ} \mathrm{E}\right], 20$ Aug. 1982 , leg. Cheng \& Li 348 (PE01727272, PE01727284, PE01727285). - MYANMAR. KACHIN. The Tri- angle (North), Tamā Bum, alt. $3200 \mathrm{~m},\left[26.83333^{\circ} \mathrm{N}\right.$, $\left.98.23333^{\circ} \mathrm{E}\right], 14$ Oct. 1953 , leg. F. Kingdon-Ward 21470 (A, two sheets; BM001050212; CAL - Bor's collection of grasses, herb. no. 537180; E00425399; K).

Calamagrostis gaoligongensis (Paszko) Paszko, comb. nov.

Basionym: Deyeuxia gaoligongensis Paszko in Paszko \& Pendry, Phytotaxa 93(1): 41. 2013.

Type: CHINA. Yunnan. Gongshan Xian [Cikai Zheng], track from Qiqi towards Dulongjiang (3000 m-3750 m), damp south-facing bank in boulder field in degraded open forest with Abies and Larix, alt. $3300 \mathrm{~m}, 27^{\circ} 41^{\prime} 30^{\prime \prime} \mathrm{N}, 98^{\circ} 27^{\prime} 25^{\prime \prime} \mathrm{E}, 15$ Oct. 1996, leg. Gaoligong Shan Expedition 1996 no. 7753 (ноLотуре: E00146585).

Calamagrostis sorengii (Paszko \& W. L. Chen) Paszko, comb. nov.

Basionym: Deyeuxia sorengii Paszko \& W. L. Chen, Nordic J. Bot. 31: 551. 2013.

Type: CHINA. Xizang. Gyangzê, waterside, alt. 3900 m, 17 July 1960, leg. G. X. Fu 847 (HOLOTYPE: PE).

AcKnowledgements. My research visit to the herbarium at Edinburgh (E) in July 2015 was supported by the SYNTHESYS Project, financed by the European Community Research Infrastructure Action under the FP7 "Capacities" Program. This study was also financed in part from statutory funds of the Institute of Botany of the Polish Academy of Sciences. I thank Bing Liu (Institute of Botany, Chinese Academy of Sciences, Beijing, China) for providing the approximate geographic coordinates for Chinese collection sites, and Jeffery M. Saarela (Canadian Museum of Nature, Ottawa) for helpful remarks and suggestions on the manuscript.

\section{REFERENCES}

Chen W. L. 2001. Validation of Deyeuxia himalaica L. Liou. Acta Phytotax. Sin. 39: 447-450.

Kingdon-Ward F. 1954. Report on the North Triangle Forest. J. Bombay Nat. Hist. Soc. 52(2-3): 304-320.

Lu S. L. 1987. Deyeuxia Clarion, Calamagrostis Adans. In: P. C. Kuo (ed.), Flora Reipublicae Popularis Sinicae 9(3): 188-229. Science Press, Beijing (in Chinese).

Lu S. L. \& Liou L. 1987. Deyeuxia Clarion. In: C. Y. Wu (ed.), Flora Xizangica 5: 213-229. Science Press, Beijing (in Chinese). 
Lu S. L., Chen W. L. \& Phillips S. M. 2006. Deyeuxia Clarion ex P. Beauvois. In: Z. Y. Wu, P. H. Raven \& D. Y. Hong (eds), Flora of China - Poaceae 22: 348-359. Science Press, Beijing \& Missouri Botanical Garden Press, St. Louis.

LudLow F. 1940. Takpo and Kongbo, S.E. Tibet. Himalayan J. 12: $1-16$.

Nobis M., Ebel A. L., Nowak A., Turginov O. T., Kupriyanov A. N., Nobis A., Olonova M. V., Paszko B., PiwowarCzyk R., Chen W. L., Gudkova P. D., Klichowska E., NowaK S. \& Pujadas-Salvà A. J. 2014. Contribution to the flora of Asian and European countries: new national and regional vascular plant records, 2. Acta Bot. Gallica 161(2): 209-221.

Paszko B. 2012. Taxonomic revision of Calamagrostis filiformis, C. tripilifera and their allies (Poaceae: Agrostidinae). Polish Bot. J. 57(2): 335-346.

Paszko B. 2014. Deyeuxia himalaica (Poaceae, Agrostidinae): taxonomy and its first record from Myanmar. Phytotaxa 156(5): 285-290.

Paszko B. \& Chen W. L. 2013. Deyeuxia sorengii sp. nov. (Poaceae, Agrostidinae) from Qinghai-Tibetan Plateau. Nord. J. Bot. 31(5): 551-555.

Paszko B. \& MA H. Y. 2011. Taxonomic revision of the Calamagrostis epigeios complex with particular reference to China. J. Syst. Evol. 49(5): 495-504.

Paszko B. \& Pendry C. 2013. Deyeuxia gaoligongensis (Poaceae: Agrostidinae), a new species from Gaoligong Shan in Yunnan, China. Phytotaxa 93(1): 40-46.

Paszko B. \& Soreng R. J. 2013. Species delimitation and name application in Deyeuxia abnormis, Agrostis zenkeri,
A. pleiophylla and related taxa (Poaceae: Agrostidinae). Phytotaxa 111(1): 1-26.

Paszko B., Chen W. L. \& Szczepaniak M. 2013. Deyeuxia debilis (Poaceae, Agrostidinae): typification, taxonomy and update of the Chinese distribution. Phytotaxa 135(1): 1-10.

Safrela J. M., Liu Q., Peterson P. M., Soreng R. J. \& Paszko B. 2010. Phylogenetics of the grass 'Aveneaetype plastid DNA clade' (Poaceae: Pooideae, Poeae) based on plastid and nuclear ribosomal DNA sequence data. In: O. Seberg, G. Petersen, A. Barfod \& J. I. Davis (eds), Diversity, phylogeny, and evolution in the monocotyledons, pp. 557-587. Aarhus University Press, Aarhus.

StEARN W. T. 1976. Frank Ludlow (1885-1972) and the Ludlow-Sherriff expeditions to Bhutan and south-eastern Tibet of 1933-1950. Bull. Brit. Mus. (Nat. Hist.), Bot. 5(5): 243-268.

Sun B. 2003a. Calamagrostis Adans. In: B. SuN, D. LI \& J. Xue (eds), Flora Yunnanica 9: 383-385. Science Press, Beijing (in Chinese).

Sun B. 2003b. Deyeuxia Beauv. In: B. Sun, D. Li \& J. Xue (eds), Flora Yunnanica 9: 372-382. Science Press, Beijing (in Chinese).

TANG C. Q. 2015. The subtropical vegetation of southwestern China. Plant distribution, diversity and ecology. In: M. J. A. Werger (ed.), Plant and vegetation 11: 1-363. Springer, Utrecht.

Wu C.-Y. \& WU S. G. 1998. A proposal for a new floristic kingdom (realm) - the Asiatic kingdom, its delineation and characteristics. In: A. ZHANG \& S. Wu (eds), Floristic characteristics and diversity of East Asian plants, pp. 3-42. China Higher Education Press, Beijing.

Received 12 September 2015 